\title{
Japan makes polluters pay after landmark court ruling
}

\section{David Cyranoski, Tokyo}

The clean-air movement in Japan scored a significant victory last week when a court judged that vehicle exhaust and industrial emissions had adverse effects on human health. Scientific evidence was pivotal in the court's ruling.

Ending an 11-year court battle, the Nagoya district court ordered the Japanese government to pay $¥ 18$ million (US\$167,000) and a group of ten industrial companies to pay $¥ 289$ million to victims of pollution.

Although small in financial terms, the ruling is likely to have far-reaching implications for Japan's air-pollution policies. The court also directed the government to enforce policies that will keep the concentration of particulates in the air to below the limits set by Japan's Environment Agency.

The Ministry of Health confirmed that the plaintiffs were suffering from pollutionrelated diseases. And the court, after hearing epidemiological evidence, judged that particulates in the air could lead to such illnesses

Two studies were particularly influential, observers say. One was a ten-year epidemiological study by the School of Public Health at Chiba University on the rates of asthma in schoolchildren living close to major roads. According to Masayuki Shima, a researcher on the study, their results showed that the likelihood of developing asthma was 3.7 times higher than average in boys and 5.9 times higher in girls who lived within 50 metres of busy roads. The researchers at Chiba attribute the difference to particulates from diesel exhaust.

In the second study, the Environment Agency's National Institute for Environmental Studies (NIES) found a clear connection between particulates and animal health. When mice were made to inhale diesel exhaust, they developed asthmatic symptoms and suffered damage to their reproductive organs. The results of five years' research were released last year in a NIES report. as "life-threatening bronchial asthma".

The Environment Agency and the ten companies have questioned the court's interpretation of these results. One Environment Agency official says: "There are so many things that are still uncertain. It is quite possible that the effect on humans is different from that on mice. Likewise, it is hard to say that the high levels of exhaust given to the lab animals are anything like those experienced by people in real life."

Masaru Sagai of Aomori University of Health and Welfare, who led the research team at NIES, responds: "It is necessary and scientific to extrapolate from experimental results - for example, from the effect of high doses over a short time to the effect of low doses over a long time."

Environmentalists say these problems would stand a better chance of resolution if the government were to invest seriously in environmental research. Compared with the United States, in particular, "Japan spends very little on researching and monitoring the effects of pollution", says Takao Nishimura, an environmental lawyer who has been involved in many such cases.

And there is some concern that successful lawsuits may diminish the government's interest in supporting pollution research. Last January, a similar ruling was given in Amagasaki, and in the months that followed, research projects allocated to Chiba University by the regional governments of Tokyo and Chiba were cut off.

Critics allege that the funding was withdrawn because of the governments' fears about the power such data would give people suing government agencies. But Shima says he has no reason to doubt that the cuts were made for the official reason given, namely the financial straits of the sponsors.

Even with financial support, says Sagai, his research has had little effect. "Once it became clear that my research on mice produced results that were disadvantageous to the agency, they ignored it altogether."

http://www.nies.go.jp

Breathe, don't breathe: a Japanese court has linked traffic fumes with childhood asthma.

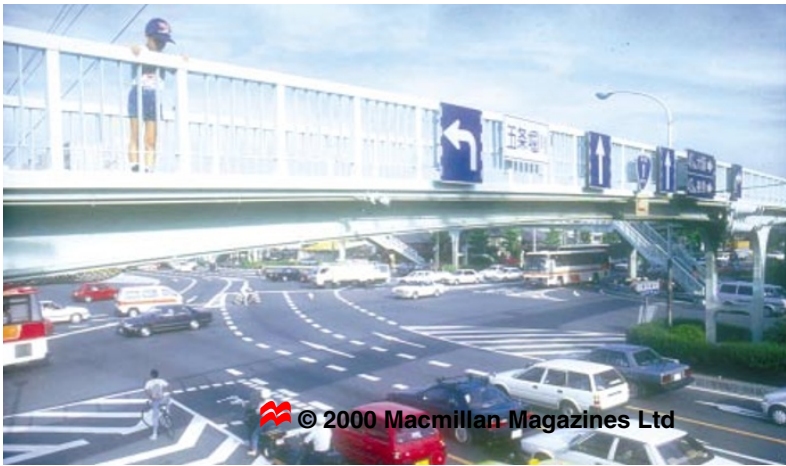

Academics bid to transcend the Arab-Israeli conflict

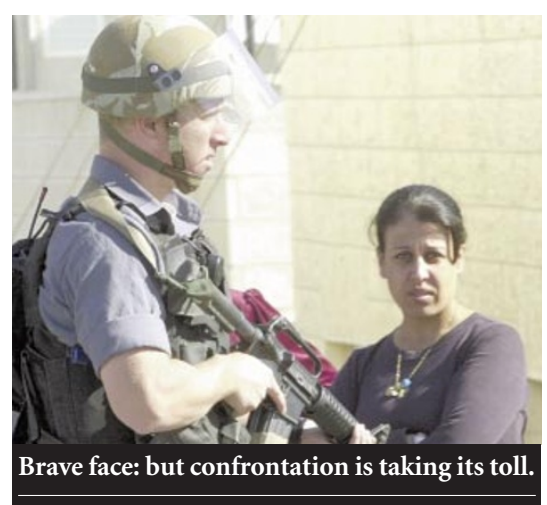

Haim Watzman

Joint research projects between Israeli and Arab scientists are continuing despite the current confrontation, but at a reduced level, scientists in the region say.

A study last summer counted 132 projects in the natural sciences involving collaboration by researchers from Israel and the Palestinian authority or other Arab countries.

There has been no comprehensive survey on the status of these projects since the outbreak of Israeli-Palestinian violence in September. But although some activities have been cancelled and military restrictions on travel have made it difficult for Palestinian students to reach Israeli campuses, researchers say that individual cooperation continues as much as possible.

Several international scientific conferences scheduled to take place in Israel have been delayed or switched to other venues. The most important was that of the Red Sea research programme, an oceanographic and environmental endeavour involving scientists from Israel, Palestine, Jordan and Egypt.

Immediately after the outbreak of violence, some scientists lost touch. Moein Kan'an, for example, a researcher at Bethlehem University who is involved in several projects with Israeli scientists, says that for the first two weeks of the conflict he heard nothing from his Israeli research partners. "We had a serious talk and resolved that we were going to proceed," says Doron Lancet of the Weizmann Institute of Science, who is working on a project with Kan'an.

The Israel Academy of Sciences and Humanities held a day-long seminar last summer to evaluate scholarly cooperation between Israelis and Arabs. Many Israeli scholars voiced their belief that science was one field in which this was increasing, although others expressed doubts. 